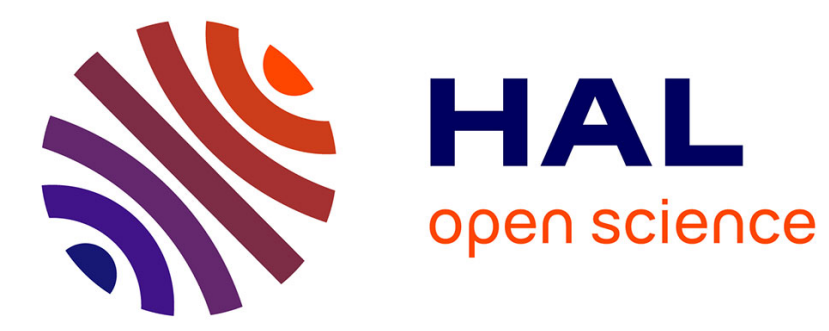

\title{
Economic valuation of the vulnerability of world agriculture confronted with pollinator decline
}

Nicola Gallai, Jean-Michel Salles, Josef Settele, Bernard E. Vaissière

\section{To cite this version:}

Nicola Gallai, Jean-Michel Salles, Josef Settele, Bernard E. Vaissière. Economic valuation of the vulnerability of world agriculture confronted with pollinator decline. Ecological Economics, 2009, 68 (3), pp.810-821. 10.1016/j.ecolecon.2008.06.014 . halshs-01293686

\section{HAL Id: halshs-01293686 https://shs.hal.science/halshs-01293686}

Submitted on 25 Mar 2016

HAL is a multi-disciplinary open access archive for the deposit and dissemination of scientific research documents, whether they are published or not. The documents may come from teaching and research institutions in France or abroad, or from public or private research centers.
L'archive ouverte pluridisciplinaire HAL, est destinée au dépôt et à la diffusion de documents scientifiques de niveau recherche, publiés ou non, émanant des établissements d'enseignement et de recherche français ou étrangers, des laboratoires publics ou privés. 
1 Economic valuation of the vulnerability of world agriculture

\section{Nicola Gallai* ${ }^{1,2}$, Jean-Michel Salles ${ }^{3}$, Josef Settele ${ }^{4}$ \& Bernard E. Vaissière ${ }^{1}$}

$4 \quad{ }^{1}$ INRA, Laboratoire Pollinisation \& Ecologie des Abeilles, UMR406 Abeilles \&

$5 \quad$ Environnement, 84914 Avignon Cedex 9, France

$6 \quad 2$ INRA, UMR LAMETA, 2 place Viala, 34060 Montpellier Cedex 1, France

$7 \quad{ }^{3}$ CNRS, UMR LAMETA, 2 place Viala, 34060 Montpellier Cedex 1, France

$8{ }^{4}$ UFZ, Helmholtz-Centre for Environmental Research, Dept. of Community Ecology,

9 Theodor-Lieser-Str. 4, 06120 Halle, Germany

10

11 *Corresponding author: Nicola Gallai, INRA, UMR LAMETA, 2 place Viala, 34060

12 Montpellier Cedex 1, France, Tel. (33) [0]4.99.61.29.67, Fax (33) [0]4.67.54.58.05, e-mail:

13 gallai@supagro.inra.fr

14 


\section{Abstract}

2 There is mounting evidence of pollinator decline all over the world and consequences in many

3 agricultural areas could be significant. We assessed these consequences by measuring 1) the

4 contribution of insect pollination to the world agricultural output economic value, and 2) the

5 vulnerability of world agriculture in the face of pollinator decline. We used a bioeconomic

6 approach, which integrated the production dependence ratio on pollinators, for the 100 crops

7 used directly for human food worldwide as listed by FAO. The total economic value of

8 pollination worldwide amounted to $€ 153$ billion, which represented $9.5 \%$ of the value of the

9 world agricultural production used for human food in 2005. In terms of welfare, the consumer surplus loss was estimated between $€ 190$ and $€ 310$ billion based upon average price

11 elasticities of -1.5 to -0.8 , respectively. Vegetables and fruits were the leading crop categories in value of insect pollination with about $€ 50$ billion each, followed by edible oil crops, stimulants, nuts and spices. The production value of a ton of the crop categories that do not depend on insect pollination averaged $€ 151$ while that of those that are pollinatordependent averaged $€ 761$. The vulnerability ratio was calculated for each crop category at the regional and world scales as the ratio between the economic value of pollination and the current total crop value. This ratio varied considerably among crop categories and there was a positive correlation between the rate of vulnerability to pollinators decline of a crop category and its value per production unit. Looking at the capacity to nourish the world population after pollinator loss, the production of 3 crop categories - namely fruits, vegetables, and

21 stimulants- will clearly be below the current consumption level at the world scale and even more so for certain regions like Europe. Yet, although our valuation clearly demonstrates the economic importance of insect pollinators, it cannot be considered as a scenario since it does not take into account the strategic responses of the markets.

25 Keywords: pollination, valuation, vulnerability, agriculture, ecosystem service, crop 


\section{$1 \quad$ Introduction}

2 The production of $84 \%$ of crop species cultivated in Europe depends directly on insect

3 pollinators, especially bees (Williams, 1994). And Klein et al. (2007) found that 87 crops, that

4 is $70 \%$ of the 124 main crops used directly for human consumption in the world, are

5 dependent on pollinators. Insect pollination is both an ecosystem service and a production

6 practice used extensively by farmers all over the world for crop production. It is an ecosystem

7 service in that wild pollinators, in particular wild bees, contribute significantly to the

8 pollination of a large array of crops (Kremen et al., 2002; Morandin \& Winston, 2005;

9 Greenleaf \& Kremen, 2006; Winfree et al., 2007 \& 2008). And it is also a management tool in

10 that honeybees, bumblebees and a few other bee species are purchased or rented by farmers in

11 many countries to supplement the local pollinator fauna (McGregor, 1976; Olmstead \&

12 Wooten, 1987; Robinson et al., 1989; Free, 1993; Dag et al., 2006). Thus the economic

13 benefit of insect pollination is clear for farmers and the market of colony rental is now well

14 developed and organized for honey bees in the United States of America (Sumner 2006) and

15 Europe (Carreck et al., 1997) as well as for bumble bees all over the world (Velthuis \& Van

16 Doorn, 2006). This practice also suggests that there is already not enough wild pollinators to

17 insure adequate pollination of all crops throughout the year in these countries. Yet the

18 abundance and diversity of wild bees as well as the abundance of honeybees are now

19 declining and some species are clearly at risk (Biesmeijer et al., 2006; National Research

20 Council, 2007; Oldroyd, 2007; Stokstad 2007). The current decline of insect pollinator

21 populations emphasizes the need to better assess the potential loss in terms of economic value

22 that may result from this trend and the possible ultimate disappearance of pollinators, and to

23 estimate the level of vulnerability of the world agriculture to insect pollinators.

Two main ways have been used to date to assess the monetary value of pollinators.

25 The first one consists in simply assessing the total value of insect-pollinated crops. This 
1 approach has been used at a national scale in the USA (Martin, 1975; Levin, 1984; Metcalf, 2 1992) as well as on a world scale (Costanza et al., 1997; Pimentel et al. 1997). Since the 3 production of most crops is only partially reduced in the absence of insect pollinators, a 4 second more refined approach to improve the previous estimate has been to introduce a 5 dependence ratio that takes into account the real impact of insect pollinators on crop 6 production. This dependence ratio enables the calculation of the production loss in case of a 7 complete disappearance of pollinators, and the economic value of insect pollination service is assimilated with the corresponding loss of crop value. Thus the monetary assessment is directly related to reported values of the dependence of crop production on the level of insect pollination and, in this paper, it will be called a bioeconomic approach. This type of 11 assessment has also been done at national and larger scales (France - Borneck \& Bricout, 1984; Hungary - Benedek, 1983; Switzerland - Fluri \& Frick, 2005; United Kingdom 13 Carreck \& Williams, 1998; USA - Robinson et al., 1989, Morse \& Calderone, 2000, Losey \& Vaughan, 2006; 12-member-states European Community - Borneck \& Merle, 1989). Unfortunately, these studies have used a wide range of dependence ratios for the same crops (Table 1). Indeed, these ratios were estimated based largely on personal communications and interpretation of review material, such as McGregor (1976) and Free (1993), which do not provide dependence ratios. None of the bioeconomic studies to date have evaluated the impact of insect pollinators at the world scale, nor did they make a geographical analysis of the impact of pollinators in terms of the possible vulnerability of agriculture or examined the 21 potential impact of pollinator loss on production compared with the consumption structure.

Our first objective was to quantify the economic loss that could result from the total disappearance of insect pollinators on world agricultural output and we based our calculations on the dependence ratios recently published for the crops used directly for human food (Klein et al., 2007). Due to the many crop species and the heterogeneity of the structure of the 
1 agricultural production, the vulnerability to pollinator decline is likely to vary widely among

2 the different continents and regions. Our second objective was therefore to provide a measure

3 of the vulnerability of the regional and world agriculture when confronted to the decline, or

4 even the total disappearance, of insect pollinators. Finally our third objective was to compare

5 the production and consumption of insect-pollinated crop categories at the regional and world

6 scale in the face of pollinator loss in order to draw some insight on potential local shortages

7 and impacts on trade. Our calculations were based on the assumption of a total pollinator loss,

8 but our results can be extended to any level of pollinator decline as there is empirical evidence

9 that the yield of entomophilous crops - that is crops that are pollinated by insects solely or in

10 a dominant way - responds linearly to pollinator density (Dedej \& Delaplane, 2003; Steffan-

11 Dewenter, 2003; Clement et al., 2007).

121 Methods

$13 \quad 1.1 \quad$ Principles

14 Among the main crops that contribute to human food, some, such as most cereals, do not

15 depend on insects for their pollination, while others can be highly or totally dependent on insect pollination, such as many fruits, vegetables and stimulant crops (Klein et al., 2007).

Our study is based on the hypothesis that the economic impact of pollinators on agricultural output is measurable through the use of dependence ratios quantifying the impact of a lack of insect pollinators on crop production value. This decrease in the production value could result from a reduction in yield as well as in quality (Free, 1993). Unfortunately, this impact on

21 production value is unknown for most crops as what is usually reported is solely the degree of dependence of the production on insect pollinators (Borneck \& Bricout, 1984; Robinson et al., 1989; Southwick \& Southwick, 1992; Morse \& Calderone, 2000; Klein et al., 2007). It is

24 this dependence ratio that we used again in our study to calculate the economic impact of 25 pollinators and the vulnerability of the agricultural output at various scales. 
Because of the lack of substitution among agricultural produce, the economic impact

2 and the vulnerability of the agricultural output is not enough to assess the full value of insect

3 pollinators as, indeed, one ton of rice is not an appropriate substitute for one ton of coffee or

4 of cantaloupe. Thus, in addition to looking at individual crops, we examined the vulnerability

5 to pollinator decline of the FAO crop categories to which each crop belonged based upon the

6 assumption that crops within a category could be considered as potential appropriate

7 substitute for one another while this would not be the case for crops in different categories.

8 We used the following 10 categories based on FAO: cereals, edible oilseed crops, fruits, nuts,

9 pulses, roots and tubers, spices, stimulant crops, sugar crops, vegetables.

\subsection{Indicators and formulae}

11 We used a bioeconomic approach to calculate the economic value of the impact of pollinator

12 loss as well as the overall vulnerability of the agricultural output to such a loss. The variables

13 used for each crop $\mathrm{i}$, where $\mathrm{i} \in[1 ; \mathrm{I}]$, in each world region $\mathrm{x}$, where $\mathrm{x} \in[1 ; \mathrm{X}]$, were the

14 quantity produced $\left(\mathrm{Q}_{\mathrm{ix}}\right)$, the quantity consumed $\left(\mathrm{C}_{\mathrm{ix}}\right)$, the dependence ratio of the crop $\mathrm{i}$ on insect pollinators $\left(\mathrm{D}_{\mathrm{i}}\right)$ and the price of crop i per unit produced in region $\mathrm{x}\left(\mathrm{P}_{\mathrm{ix}}\right)$. We used the price of each crop in each of the 5 regions of the world (sensu FAO; see supplementary material - Appendix 1) because, despite the growing interdependence of agricultural markets, producer prices for the same crop may vary widely from one region to another and therefore cannot be appropriately summarized by a single average world price. Indeed, we found that neither the FAO database nor that of any other world organization provided these prices on a

21 worldwide basis for all our study crops. The total economic value of insect pollination (IPEV)

22 was then calculated as follows:

$$
\mathrm{IPEV}=\sum_{i=1}^{I} \sum_{x=1}^{X}\left(P_{i x} \times Q_{i x} \times D_{i}\right)
$$


Following White (1974), a precise definition of vulnerability was given by Turner et al.

2 (2003) and used by Schröter et al. (2005) to assess the vulnerability of Europe faced with

3 global change. Vulnerability is a function of three elements: exposure, sensitivity and

4 adaptive capacity. In this context, we used the ratio of the economic value of insect

5 pollination to the economic value of the crop (EV) to calculate a level of vulnerability since it

6 provides a measure of the potential relative production loss attributable solely to the lack of

7 insect pollination. The ratio of vulnerability (RV) for the world output used for human food

8 was thus calculated as follow:

9

$$
\mathrm{RV}=\frac{\mathrm{IPEV}}{\mathrm{EV}}=\frac{\sum_{i=1}^{I} \sum_{x=1}^{X}\left(P_{i x} \times Q_{i x} \times D_{i}\right)}{\sum_{i=1}^{I} \sum_{x=1}^{X}\left(P_{i x} \times Q_{i x}\right)}(\%)
$$

So defined, the agricultural vulnerability to pollinator decline depends upon crop dependence to pollinators, and farmers' capacity to adapt to pollinator decline. We used part of the overall matrix to calculate the vulnerability of a crop, of a crop category, and of the agricultural industry in a given region when faced with pollinator decline. calculated the 2005 relative overproduction as:

$$
\frac{\sum_{i=1}^{I} \sum_{x=1}^{X}\left(Q_{i x}-C_{i x}\right)}{\sum_{i=1}^{I} \sum_{x=1}^{X}\left(C_{i x}\right)}
$$

The corresponding matrix after total pollinator loss was:

$$
\frac{\sum_{i=1}^{I} \sum_{x=1}^{X}\left(Q_{i x}\left(1-D_{i}\right)-C_{i x}\right)}{\sum_{i=1}^{I} \sum_{x=1}^{X}\left(C_{i x}\right)}
$$


2 The geographical scale of our study was the world based upon the 2005 data from the FAO database (http://www.fao.org) and thus restricted to the 162 countries that are members of this

4 international organization. Following FAO definitions, we gathered these countries into 5 main regions (Africa, Asia \& Oceania, Europe, North America and Caribbean, South and Central America), and, within each region, into sub-regions (see supplementary data Appendix 1).

We limited the scope of our study to the direct crops and commodity crops used directly for human food as reported by FAO (see supplementary data - Appendix 2). Direct crops are those listed individually with their production by the FAO while a commodity is an 11 aggregation of different crops for which the production figures are pooled together and most are reported as Not Elsewhere Classified. Commodity production figures are based on a questionnaire that countries fill out to include important crops for the world market that are not listed individually by the FAO. We included the commodity crops in the study because they represent a significant part of the agricultural world output.

For $\mathrm{Q}_{\mathrm{ix}}$ and $\mathrm{C}_{\mathrm{ix}}$, we used the $2005 \mathrm{FAO}$ production and consumption data, respectively (http://www.fao.org). For $\mathrm{P}_{\mathrm{ix}}$, we needed the mean 2005 producer price per unit weight for each crop or commodity and each region as we opted to take into account regional specialization, geographical context, and socio-economic factors. We chose this approach because producer prices vary with many factors such as crop management, climate, varieties and market in such a way that a regional approach should provide more accurate price estimates than a worldwide approach. To fit complex geographical patterns as well as to be able to concentrate on large producing regions without having to go to the level of individual countries for which many price data are not available either, we used the five main world regions defined previously (see supplementary data - Appendix 1). Major world field crops, 
1 like most cereals and sugar crops, are produced on a large scale and have a large-enough

2 commercial value to be traded on financial markets. For these crops, we used the "free on

3 board" (FOB) prices, which are future contracts for 2005. These prices are available on the

4 websites of financial market places specialized in commodities such as the Chicago Board of

5 Trade (CBOT) and the New York Board of Trade (NYBOT). For most other crops, prices are

6 not available on the financial market place because of lower interest in their international

7 trading on a large scale. For these crops, we used the 2005 producer prices for each world

8 region that were provided by the European database Eurostat

9 (http://epp.eurostat.ec.europa.eu) and by the United States Department of Agriculture

10 (http://www.fas.usda.gov). For minor crops, defined as those for which the 2005 producer

11 price was not available in either of these two large databases, as well as for all the

12 commodities, we used the average producer price listed on the FAOSTAT website for the period 1991-2002 for the most important producing country of each world region. We used this method to reduce the effect of year-to-year price variation as well as the biases on prices that might take place in small producing countries. Furthermore, when a country or a world region largely exceeded its expected share of world production for a given crop based on its sole size, we considered it to be specialized in this crop. For example, Asia produced $90 \%$ of the rice, so we assumed that the world demand for rice, and thus its world price, would be influenced by the Asian supply. In this example, we took the producer price of Asia rice and applied it on a worldwide basis. In all cases, we used the local currency and the exchange rate 21 of the years of the data collected to calculate the prices and production values in 2005 euros. recent review of Klein et al. (2007; see supplementary data - Appendix 2). Starting with the complete set of direct and commodity crops used for human food, we selected the ones for which we had production and price data. For the individual crops among the 11 commodities, 
1 neither the production nor the producer price was available and the crops that composed each

2 of these commodities were not all dependent on insect pollination at a similar level for their

3 production. Consequently we could not calculate the economic value of pollinators for these

4 commodity crops and they were not considered further. For the direct crops, we focused on

5 those reviewed in Appendices 1 and 2 of Klein et al. (2007) for which we calculated the

6 average dependence ratio based on the reported range of dependence to animal-mediated

7 pollination in this work (See supplementary data - Appendix 2).

\section{$8 \quad 2$ Results}

9 We found 89 direct crops and 11 commodities used for human food (100 lines in Appendix 2). Among these, 46 direct crops in 7 categories are dependent on insect pollinators for their

11 production and pollinators are essential for 6 of these crops. The contribution of insect pollinators is also reported as great for 13 direct crops, modest for 13 and little for 14

13 (Appendix 2). It is noteworthy that within each crop category, there was considerable 14 variation among the crops as to their level of dependence on pollinators.

The 2005 world production value for crops used for human food was $€ 1618$ trillion, and the total value of the 46 insect-pollinated direct crops was $€ 625$ billion, that is $39 \%$ of the world production value (Table 2 and supplementary data in Appendix 3). The economic value of insect pollination was $€ 153$ billion (Table 2). The most pollinator-dependent crop categories ranked by decreasing economic value of insect pollination were vegetables, fruits, and edible oil crops (Table 2). It is noteworthy that the production value of a ton of the crop categories that do not depend on insect pollination - namely cereals, sugar crops, and roots \& tubers - averaged $151 €$ while that of those that are pollinator-dependent averaged $761 €$, or five times more, and these values were significantly different $(t=4.851 ; \mathrm{n}=3$ and 7 , respectively; $P=0.0013 ; t$ test on the Log-transformed values to have similar variance among the two groups). 
The rate of vulnerability of the world agricultural production used for human food in

2 the face of total pollinator loss was $9.5 \%$ (Table 2 ). This overall value may seem small, but it does not reveal the large range of values among the different crop categories. The stimulant crops with a total production value of only $€ 19$ billion had the highest vulnerability ratio (39\%). And vegetables, the category with the highest crop production value (€418 billion) still had a vulnerability ratio of $12 \%$. Interestingly, there was a positive correlation between the rate of vulnerability of a crop category to pollinators and its value per production unit $(\mathrm{r}=$ $0.729, \mathrm{n}=10, P=0.017)$.

Looking at the economic vulnerability ratios of the different crop categories among the regions of the world indicates that, in each region, there is a category that is highly vulnerable to pollinator loss with vulnerability ratios ranging from $22 \%$ to $94 \%$ (Table 4 ). Interestingly, nuts were the most vulnerable crop category over the largest area (7 subregions), followed by fruits and stimulant crops ( 5 sub-regions each). Furthermore, because some regions are specialized in the production of some pollinator-dependent crop category, the vulnerability of the world production for these categories is much higher than the overall worldwide value indicated on Table 3. For example, East Asia produced nearly $52 \%$ of the world vegetables with a vulnerability ratio of $15 \%$ while the worldwide value was $12 \%$ (Tables 2 and 4). Also North and South Americas produced 36\% of the edible oil crops with a vulnerability ratio greater than $22 \%$, while the worldwide value was $16 \%$ (Tables 2 and 4 ). And West Africa, South East Asia and North America together produced 36\% of the nuts in

21 the world with a vulnerability ratio $\geq 44 \%$ in all three regions. The situation appeared particularly critical for stimulant crops as West Africa produced 56\% of the world production with a vulnerability ratio of $90 \%$ (Table 4 ). This region produced a lot of coffee and/or cocoa,

24 both of which are dependent of insect pollinators for their production, and the consequences 25 of a total pollinator loss on these crops could be considerable not only for the revenues that 
1 West Africa derives from these crops, but also on a global scale for the world production and

2 resulting price structure of these stimulants.

On a global scale, the difference between production and consumption in 2005 was

4 positive for all crop categories that are pollinator-dependent ${ }^{1}$. Looking at these same

5 differences after total pollinator loss, the overall world food supply would not be in jeopardy,

6 but the production drop would create a deficit in three crop categories including fruits and

7 vegetables, two pollinator-dependent categories with a high economic value and low ability

8 for storage from one year to the next (Table 5). Looking at these three categories for which

9 the overall production would no longer meet consumption patterns after total pollinator loss,

we examined their change in availability in each geographical region. The deficit resulting

11 from the loss of pollinators appears important in many region and crop category combinations, and it could have some serious consequences in two types of situations. First, in some regions where production was clearly exceeding consumption, the loss of pollinators would result in a deficit such that production would no longer be able to meet consumption. This is the case for fruits in North Africa as well as in Central, East and South Asia (Table 6).

16 A case in point is East Asia where fruit production exceeded consumption by $19 \%$ in 2005 17 and where total pollinator loss would result in a deficit with consumption exceeding production by $26 \%$, which is considerable since this region produces nearly $20 \%$ of the world fruit output. Other examples of a similar situation of consumption exceeding production as a consequence of pollinator loss are found (i) for vegetables in North and South Africa, East 21 and Middle East Asia, and South America, and (ii) for stimulant crops in South Africa. A second type of situation where pollinator loss could have serious consequences arises for regions which are already barely meeting their consumption patterns or which are net 23

${ }^{1}$ This global statement is not in contradiction with the fact that, according with the World Health Organization (WHO) some 3.7 billion people were malnourished in 2005 or, following the Food and Agricultural Organization (FAO) estimates, 850 million, as FAO recorded only the people that are protein/calories malnourished, rather than nutrient deficient. 
1 importers for a given crop category and could therefore be severely impacted by the drop of

2 production following pollinator loss. This is the case for example with fruits in the European

3 Union where consumption exceeded production by $20 \%$ in 2005 and this deficit would double

4 following total pollinator loss in Europe. Other examples include fruits in West Africa and

5 North America, vegetables in Central Africa, Oceania, the European Union and North

6 America, and stimulant crops in the European Union and North America.

73 Discussion

8 We found a value of about $€ 153$ billion as an assessment of the economic value of insect

9 pollination for the world agriculture in 2005. This is the direct result of the calculations based on equation [1] using the dependence ratios towards pollinators given by a recent review

11 (Klein et al., 2007) and the production value of the most important crops directly used for human food. It measures the part of the gross value of the world food production attributable

13 to insect pollination and can therefore be considered as a conservative assessment of the gross

14 value of the insect pollination service. Indeed, in an early valuation of the service provided by 15 bees on US agriculture, Martin (1975) stated that the value of beef and dairy products that result from the seed production of forage legumes such as alfalfa accounts for about $80 \%$ of

17 the economic value of insect pollinators. At the world scale, such a high value is most unlikely, at least because forage legume are not as important worldwide as in the USA. But this statement nevertheless underlines the fact that the indirect impact of pollinator decline on 20 forage production, though quite difficult to assess, may not be anecdotal. Similarly, our assessment did not take into account the value of pollinators for the seed production necessary to grow the vegetative parts of many species which are consumed by humans (such as many vegetables; see Appendix 1 in Klein et al. 2007, and our supplementary data - Appendix 2), nor the seed production for ornamental flowers and other uses not devoted to human food 25 such as biofuels. Soybean and other pollinator-dependent edible oil crops contribute to the 
1 supply of biofuels, but current relative prices limit their use and biofuels are mainly produced

2 from non-pollinator dependent crops such as sugar cane and corn (Schubert, 2006; Appendix $32)$.

In the literature, we found only two studies giving an economic valuation of the pollination service at the world scale (Costanza et al., 1997; Pimentel et al., 1997). Yet the comparison of our results with those of these two studies is difficult because their methods are so different. Costanza et al. used the findings of Levin (1984) to determine a lower limit of the value of insect pollination service of US\$140 million, corresponding to the value of honey and beeswax in 1980, and an upper limit of US\$18.9 billion, which was the value of 1980 U.S crops that they considered dependent on insect pollinators (fruits, nuts, vegetables, seeds, 11 fibers, cattle, calve and liquid milk production). Conservatively and without further 12 justification, they chose a value of US\$2 billion from this interval and assumed that the U.S. agriculture represented $10 \%$ of the world crop value. In this way, they found a value of the insect pollination service to crops worldwide of US\$20 billion for 1996 which amounts to about $€ 20$ billion when adjusted for inflation (http://data.bls.gov) and 2005 exchange rate (http://fxtop.com). Pimentel et al. (1997) started with the figure of US\$8 billion reported by Martin (1975) and quoted in Robinson et al. (1989) for the 1970 value of USA crops dependent on insect pollinators and used for human food. Martin increased this figure to US\$ 40 billion when adding the value of beef and dairy products that are derived from insectpollinated legume forage to the value of crops used directly for humans. Then, Pimentel et al. extrapolated this value to the entire world by assuming that the economic value of insect pollination worldwide was at least five times that of the USA. With appropriate exchange rate 23 and inflation correction, the figures of Pimentel et al. (1997) give an economic value of insect 24 pollination to the world agriculture of US\$200 billion in 1996, and gives a 2005 economic value of $€ 200$ billion, which takes into account the value of beef and dairy products that are 
1 derived from insect-pollinated forage legumes. Interestingly, if we start with the original

2 figure of US\$ 8 billion for the crops used for human foods only, the economic value of insect

3 pollination worldwide amounts to US\$40 billion ( $€ 40$ billion in 2005 economic value).

Even after appropriate corrections, the 2005 estimated values from these two studies (€20 billion and $€ 40$ billion for Costanza et al., 1997 and Pimentel et al., 1997, respectively) remain considerably smaller than our result ( $€ 153$ billion; Table 2$)$. Such a difference raises many questions. Since these authors give little explanations on their methods, we might assume that they have integrated in their calculations some more sophisticated - though unformulated - considerations, especially in relation to the behavior of economic actors that will adapt to a pollinator-free context. for human food. This ratio of vulnerability can be interpreted as an indicator of the value of 13 pollination service relatively to the other factors that contribute to agricultural production worldwide. The value of the vulnerability ratio is of course contingent upon the relative prices of crops and, especially, the prices of pollinator-dependent crops relative those which are not ${ }^{2}$. It must be clearly stated that this economic valuation is not a scenario assessment, since all economic agents can change their behavior in order to adapt to a pollinator decline. These changes will have some costs, namely opportunity costs. But one can assume that producers will make efficient trade-offs between the costs of changing crop species, or varieties, or production technologies - namely pollination techniques - and the losses

21 resulting from keeping less profitable practices ${ }^{3}$.

\section{1}

${ }^{2}$ It must be mentioned that crops vary in the manner in which their prices behave. Tropical fruits and spices also suffer from price volatility, which produce losses or windfall gains. There are high price regimes and low price regimes as in the case of coffee and spices (also bee-pollinated crops) coinciding with crop failures in major producing countries such as Brazil (for coffee) and Guatemala (for cardamom). This might implicitly mean high elasticity of demand in high price regimes and low elasticity in low price regimes.

${ }^{3}$ For orchard crops that are perennial in nature, elasticity of adaptation measures such as shifting to other crops is low. Supply elasticity for perennial crops tends to be low as compared to demand elasticity. As a result, the 
It appears difficult to gauge the real significance of a vulnerability of about $10 \%$ on

2 the agricultural industry. In some cases, a small variation may induce large consequences,

3 especially through the impact it might have on the financial equilibrium of farms. The

4 transmission of the price change can have variable effects within the food supply chain $(\mathrm{Wu}$, 5 2004; Tang, 2005) and the capacity of the food supply chain operators to adapt to new

6 situations and limit the consequences, either through technical change or because of the 7 existence of market power, is poorly known (Hassan and Simioni, 2001).

Furthermore, the decline of pollinators will certainly be heterogeneous among different regions of the world due to differences in land and crop management as well as the abundance and diversity of wild and managed bees. For example, in a reverse scenario 11 Roubik \& Wolda (2001) found that the arrival of Africanized honey bees in South and Central America resulted in much higher population densities of bees, and this translated into increased coffee production (Roubik, 2002). On a smaller scale, landscape management is also likely to affect pollinator density (Kremen et al., 2002; Klein et al., 2007).

A first step towards a better understanding of the meaning of a $10 \%$ vulnerability ratio could consist in introducing an economic measure of this vulnerability in terms of consumer surplus. Southwick and Southwick (1992) estimated the economic value of honeybees as agricultural pollinators in the USA based upon a measure of the surplus gain resulting from their pollination service. They considered a price reaction to quantity limitation related to the dependence ratio that leads to the following expression of the consumer monetary surplus gain for each crop:

$$
\text { Gain }=Q_{1}\left(P_{1}-P_{0}\right)+\int_{Q_{1}}^{Q_{0}}\left[P(Q)-P_{0}\right] d Q
$$


1 where $\mathrm{P}_{0}$ and $\mathrm{Q}_{0}$ are the price and quantity with honeybee pollination, the price $\mathrm{P}$ was

2 estimated as a function of the quantity $\mathrm{Q}$ and the income of American households from

3 temporal series, $\mathrm{P}_{1}$ and $\mathrm{Q}_{1}$ are the price and quantity without honeybee pollination.

Our assessment is based upon the calculation of the loss in terms of agricultural 5 production for each crop $\mathrm{i}$, that is $\mathrm{P}_{\mathrm{i} 0}\left(\mathrm{Q}_{\mathrm{i} 0}-\mathrm{Q}_{\mathrm{i} 1}\right)$ (see Figure 1). This result must be 6 transformed into economic surplus loss for consumers to obtain an assessment of the social 7 cost of pollinator decline. Since there are no appropriate data to find econometrically for each crop at the world scale the price elasticities, assumptions must be made on the shape and value of $\mathrm{P}(\mathrm{Q})$. A simple idea is to assume that for all crops the price elasticities (E) are constant. Inverse demand functions can then easily be expressed and consumer surplus

11 variations analytically calculated.

The choice of a constant elasticity price is acceptable for most crops as long as the price range remains in the neighborhood of current prices. The neighborhood wideness is variable with the crop and its economic status as primary good or luxury good. It is probably unacceptable when the ratio of dependence is very high, since the price should then rise considerably (e.g. for the 6 crops with a dependence ratio of $95 \%$, which means that for a

17 price elasticity value of -1 , the price following total pollinator loss would be multiplied by $1820)$.

Given a constant elasticity price, the mathematical representation of the demand

20 function comes from the definition of the price-elasticity $\mathrm{E}=\frac{\delta Q / Q}{\delta P / P}$, which leads to

$21 P(Q)-E Q P^{\prime}(Q)=0$ and, assuming $\mathrm{E} \neq 0$, gives the inverse demand function:

$$
P(Q)=P_{0}\left(\frac{Q}{Q_{0}}\right)^{\frac{1}{E}}
$$


We will also assume, following Southwick and Southwick (1992), that the long-term

2 supply curve is perfectly elastic, which means that farmers can switch from one crop to another without increasing production cost and without constraint of arable land availability.

4 It means that there is no producer surplus variation and then the consumer surplus variation is actually the social surplus variation.

We used the large matrix that was built to measure the economic value of insect pollination (Appendices 2 and 3) to calculate what would be the consumer surplus loss according to several price elasticity values. For each value, we applied our hypotheses to each crop with its specific dependence ratio to pollinators.

The choice of a unique value for E may seem like an oversimplification. But choosing different values of $\mathrm{E}$ for each crop in each region would be equally arbitrary since these values could not be determined from appropriate econometric data. Some crops, like cereals, are generally associated with low price elasticities, usually estimated to be $|\mathrm{E}|<0.5$ in the literature. Other crops, such as fruits, appear to have higher price-elasticities, $|E|>1$ and possibly much more in some cases (Southwick and Southwick, 1992).

The choice of the unique value of $\mathrm{E}$ for all crops must take into account the relative importance of crops with high and low elasticities, which are used to calculate the total consumer surplus loss. Fruits, vegetables, nuts, edible oil crops, stimulant crops, and spices are the most pollinator-dependent crop categories and they are also those that will make the largest part of the total loss. Yet they are also those that appear most likely to have the highest

21 elasticities. So the overall appropriate figure for E is likely to be in the neighborhood of -1 .

22 Furthermore, a distinction must be made between short-term and long-term elasticities, the 23 latter being traditionally higher $(|\mathrm{E}|>1)$. Since we consider a hypothetical situation of total 24 pollinator loss, long-term elasticities appear more appropriate. 
We have to assess now what will happen to the food production and markets after

2 insect pollinators decline to a complete loss. The first consequence is a loss in production

3 from $\mathrm{Q}_{0}$ to $\mathrm{Q}_{0}(1-\mathrm{D})$ for a similar production effort (i.e. without change in the total production

4 costs). If a smaller production is obtained for the same total cost, we can assume that the

5 unitary production cost will grow from $\mathrm{P}_{0}$ to $\mathrm{P}_{0} /(1-\mathrm{D})=\mathrm{P}_{1}$. We will then consider that $\mathrm{P}_{\mathrm{i} 1}$ is

6 the new price of the crop $i$ on the market of our pollinator-free economy. At this price, the

7 effective demand will be $\mathrm{Q}_{\mathrm{i}}\left(\mathrm{P}_{\mathrm{i} 1}\right)=\mathrm{Q}_{\mathrm{i} 1}$. This assumption allowed us to calculate the consequent surplus loss (CSloss; Figure 1) according to the value of E.

$$
\text { CSloss }_{\mathrm{i}}=Q_{i 1}\left(P_{i 1}-P_{i 0}\right)+\int_{Q_{i 1}}^{Q_{i 0}}\left[P_{i}\left(Q_{i}\right)-P_{i 0}\right] d Q
$$

For the value $\mathrm{E}=-1$, it comes from $[6]$ that $\mathrm{P}(\mathrm{Q})=\mathrm{P}_{0} \cdot \mathrm{Q}_{0} / \mathrm{Q}$, and $\mathrm{Q}_{1}\left(\mathrm{P}_{1}-\mathrm{P}_{0}\right)=\mathrm{P}_{0}\left(\mathrm{Q}_{0^{-}}\right.$

$\left.11 \mathrm{Q}_{1}\right)$. The consumer surplus loss is then:

$$
\text { CSloss }=\int_{Q_{1}}^{Q_{0}}[P(Q)] d Q=\int_{Q_{0}}^{Q_{1}} \frac{P_{0} Q_{0}}{Q} \delta Q=P_{0} Q_{0} \log \frac{Q_{1}}{Q_{0}}
$$

where $\mathrm{P}_{1}$ and $\mathrm{Q}_{1}$ are the price and quantity without insect pollination, $\mathrm{P}_{0}$ and $\mathrm{Q}_{0}$ are the price and quantity with insect pollination. If we apply this expression to a quantity reduction related to a total pollinator loss for a crop with a ratio of dependence $\mathrm{D}, \mathrm{Q}_{1}=\mathrm{Q}_{0}(1-\mathrm{D})$ and it comes: CSloss $=P_{0} \cdot Q_{0} \cdot \log (1-D)$. This value is easy to calculate using the matrix of prices and quantities in Appendices 2 and 3. Applying this formula to all crops used directly for human food on a worldwide basis gives a total loss of consumer surplus of about $€ 260$ billion for 2005.

For any price-elasticity $\mathrm{E} \neq-1$, it comes:

$$
\text { CSloss }=\frac{P_{0} Q_{0}}{1+E}\left(\left(\frac{1}{1-D}\right)^{1+E}-1\right)
$$


1 region (Appendices 2 and 3):

$$
\sum_{i=1}^{I} \sum_{x=1}^{X} \frac{P_{i x 0} Q_{i x 0}}{1+E}\left(\left(\frac{1}{1-D_{i}}\right)^{1+E}-1\right)
$$

3 For $\mathrm{E}=-0.8$, we find $€ 310$ billions; and for $\mathrm{E}=-1.5$, about $€ 191$ billion (see Table 7).

Though a more refined analysis remains to be done, it is possible to suggest some changes that are likely to take place in the behavior of producers, agro food supply chains, and consumers, if the decline in insect pollination services is further confirmed. Farmers would at least to some extent switch from pollinator-dependent crops to less dependent species or, when available, varieties. But a first reaction would probably be in many cases, as it is widely done for fruit production in the USA, to try to improve insect pollination through the management of selected species and the development of artificial pollination techniques.

For the rare pollinator-dependent crops with low price elasticity $(|E|<1$; i.e. apples with $E=-0.59$, (Southwick \& Southwick, 1992) the farmers' income will increase when yields decrease since prices will rise faster ('King effect'). This effect should nevertheless be limited by competition among farmers and resulting production enhancing investment. aim at reducing the impact of pollinator decline onto consumers, through substitution both in the nature of the good and the processing formula. Finally, consumers would modify their choices according to the relative prices of food items and, in the case of strong change; the food budget might compete with other parts of the consumption patterns ${ }^{4}$.

21 economic terms only, as it might also have serious consequences on human health. In 21

\footnotetext{
${ }^{4}$ The emergence of organic foods and widespread concerns about GM foods has reduced elasticity of substitution for health foods (organic and non GM traditional foods) despite health foods carrying higher prices. Finally, the loss in output of conventional pollinated crops due to inadequate pollination forms a deadweight loss, net loss to producer and consumers and hence to society.
} 
1 particular, the decrease of fruit and vegetable availability could impact the health of

2 consumers worldwide. The World Health Organisation (WHO) has set a lower limit of 400

3 grams per capita and per day for fruit and vegetable consumption (WHO Report, 1990).

4 Naska et al. (2000) studied fruit and vegetable consumption among ten European countries

5 and found that more than $50 \%$ of the households were below this recommendation. In the

6 case of a total disappearance of pollinators, this situation is very likely to worsen.

74 Conclusions

8 The aim of our work was to assess the vulnerability of the food production worldwide faced

9 to the decline of insect pollinators. Non-food agricultural production, cattle raising, and natural vegetation will also be impacted but are not studied in this paper. Using a

11 bioeconomic approach, we calculated a world value for the contribution of pollinators to the production of crops used directly for human food of $€ 153$ billion, which is about $9.5 \%$ of the 13 total value of the production of human food worldwide.

Since this first result was obtained through multiples sums, we extracted partial results such as the most vulnerable crop categories (stimulant crops, nuts and fruits) or the categories that stood for the largest part of the economic vulnerability (fruits, edible oil crops, vegetables). Related to their agricultural orientations, some regions appeared more vulnerable like Middle East Asia (15\%), Central Asia (14\%), East Asia (12\%) and non European Union 19 countries $(12 \%)$. At the global scale, the vulnerability of the Northern countries appeared 20 higher than the southern ones, which suggests that the decline of insect pollinators might have 21 heavy consequences for the North-South agro-food trade. To complete these data, we 22 calculated the capacity to nourrish world population after pollinator loss and found that the 23 production of 3 crop categories will be clearly below the current consumption at the world 24 scale and even more so for certain regions like Europe. 
Although we created a complete database of prices and production quantities for each crop in each region of the world and we used a very recent review to get the dependence ratio of each crop on insect pollination, the uncertainties are probably large but difficult to assess, especially since ecological responses to pollinator decline on large scales remain poorly known (National Research Council, 2007). More specifically, there is an ongoing debate on the existence of a "pollinator paradox" meaning that though crops depend on pollinators, the overall crop yield may not necessarily be as dependent because farmers will take into account pollinator decline in their production management and strategies (Ghazoul, 2007). loss, which is a more appropriate indicator of the economic valuation of these vulnerabilities. Since it was not possible to rely on econometrically estimated price elasticities for each crop in each region, our calculations relied on the assumption of an average sensitivity of prices to quantity shortage. Stating that the most vulnerable crops appear to be more sensitive to price variation, the more realistic elasticity parameter is likely to be $|E|>1$. Furthermore, since we considered the evolution over the long term, we can make the optimistic assumption that farmers would adapt without significant cost, and the social surplus losses would be in the range of $€ 310-191$ billions for elasticity parameters ranging from -0.8 down to -1.5 .

Although our results demonstrate the economic importance of insect pollinators, it cannot be considered as a scenario since it does not take into account the strategic response of the market. Producers might have several levels of response strategies in interaction with the intermediate demands of the food supply chain. Moreover, the response of consumers faced to dramatic changes of relative prices would probably be more elaborate than the simple priceelasticity can summarize. Short and long term reaction for each crop and in each region would probably be quite different and should be studied specifically in further work. 


\section{Acknowledgements}

2 This research was funded by the EC within the FP6 Integrated Project "ALARM" (Assessing

3 LArge scale environmental Risks for biodiversity with tested Methods; GOCE-CT-2003-

4 506675; http://www.alarmproject.net; Settele et al., 2005). The authors thank Joshua Bishop, Jean-Marie Boisson, Gabriel Carré, Charles Figuières, Ghislain Géniaux, Mabel Tidball and three anonymous referees for valuable comments on an early version of this text.

\section{References}

Biesmeijer, J. C., Roberts, S. P. M., Reemer, M., Ohlemüller, R., Edwards, M., Peeters, T., Schaffers, A. P., Potts, S. G., Kleukers, R., Thomas, C. D., Settele, J., Kunin, W.E., 2006. Parallel declines in pollinators and insect-pollinated plants in Britain and the Netherlands. Science 313, 251-353.

Benedek, P. 1983. Economic importance of honey bee pollination of props at the national level of Hungary. 29th International Apiculture Congress: Apimondia, 286-289.

Borneck, R., Bricout, J.P. 1984. Evaluation de l'incidence économique de l'entomofaune pollinisatrice en agriculture. Bulletin Technique Apicole 11(2), 117-124.

Borneck, R., Merle B. 1989. Essai d'une évaluation de l'incidence économique de l'abeille pollinisatrice dans l'agriculture européenne. Apiacta 24, 33-38.

Carreck, N., Williams, I. 1998. The economic value of bees in the UK. Bee World 79, 115123.

Carreck, N.L., Williams, I.H., Little, D.J. 1997. The movement of honey bee colonies for crop pollination and honey production by beekeepers in Great Britain. Bee World 78, 67-77.

Clement SL, Hellier BC, Elberson LR, Staska RT, Evans MA. 2007. Flies (Diptera: Muscidae: Calliphoridae) are efficient pollinators of Allium ampeloprasum L. (Alliaceae) in field cages. Journal of Economic Entomology 100, 131-135.

Costanza, R., D'Arge, R., De Groot, R., Farber, S., Grasso, M., Hannon, B., Limburg, K., Naeem, S., O'Neill, R. V., Paruelo, J., Raskin, P., van den Belt, M., 1997. The Value of the world's ecosystem services. Nature 387, 253-260.

Dag, A., Zipori, I., Pleser, Y., 2006. Using bumblebees to improve almond pollination by the honeybee. Journal of Apicultural Research 45, 215-216. 
1 Dedej S, Delaplane KS. 2003. Honey bee (Hymenoptera: Apidae) pollination of rabbiteye blueberry Vaccinium ashei var. 'Climax' is pollinator density-dependent. Journal of Economic Entomology 96, 1215-1220.

Eurostat. Statistical Database. Available at http://epp.eurostat.ec.europa.eu ; Agriculture, forestry and fisheries themes/Agriculture/Agricultural prices and price indices. Last accessed in October 2006.

Food and Agriculture Organization. Statistical Database. Available at http://faostat.fao.org; Agricultural data/Agricultural production/Crops primary. Last accessed in July 2007.

Fluri, P., Frick, R. 2005. L'apiculture en Suisse: état et perspectives.. Revue Suisse d'Agriculture 37(2), 81-86.

Free, J. B., 1993. Insect pollination of crops. London, UK: Academic Press. 544 pp.

Ghazoul, J., 2007. Recognizing the complexities of ecosystem management and the ecosystem service concept. GAIA 16, 215-221.

Greenleaf, S. S., Kremen, C., 2006. Wild bees enhance honey bees' pollination of hybrid sunflower. Proceedings of the National Academy of Sciences USA 103, 13890-13895.

Hassan, D., Simioni, M., 2001. Price Linkage and Transmission between Shippers and Retailers in the French Fresh Vegetable Channel. Working paper, INRA-ESR, Toulouse.

Klein, A.-M., Vaissière, B. E., Cane, J.H., Steffan-Dewenter, I., Cunnigham, S. A., Kremen, C., Tscharntke, T., 2007. Importance of pollinators in changing landscapes for world crops. Proceedings of the Royal Society 274, 303-313.

Kremen, C., Williams, N. M., Thorp, R. W., 2002. Crop pollination from native bees at risk from agricultural intensification. Proceedings of the National Academy of Sciences USA 99, $16812-16816$.

Levin, M. D., 1984. Value of bee pollination to United State agriculture. American Bee Journal 124, 184-186.

Losey, J. E., Vaughan, M., 2006. The economic value of ecological services provided by insects. BioScience 56, 311-323.

Martin E. C., 1975. The use of bees for crop pollination. In: Dadant \& Sons (Editors), The hive and the honey bee. Hamilton, Illinois, pp. 579-614.

McGregor, S. E., 1976 Insect pollination of cultivated crop plants. Agriculture Handbook, United States Department of Agriculture, Washington DC. (available at http://gears.tucson.ars.ag.gov/book/). 
1 Metcalf R.L., Metcalf R.A., 1992. The Value of insects to humans, In : Destructive and Frank J. Kotowski, Jr., ed.

Morandin, L.A., Winston, M.L., 2005. Wild bee abundance and seed production in conventional, organic, and genetically modified canola. Ecological Applications 15, 871881.

Morse, R. A., Calderone, N. W. 2000. The value of honey bees as pollinators of U.S. crops in 2000. Bee Culture, 1-15.

Naska, A., Vasdekis, V. G. S., Trichopoulou, A., Friel, S., Leonhäuser, I. U., Moreiras, O., Nelson, M., Remault, A. M., Schmitt, A., Sekula, W., Trygg, K. U., Zajkas, G. 2000. Fruit and vegetable availability among ten European countries: how does it compare with the 'five-a-day' recommendation? British Journal of Nutrition 84, 549-556.

National Research Council of the National Academies, 2006. Status of Pollinators in North America. National Academy of Science, Washington, D.C., 303 pp.

Olmstead, A.L., Wooten, D.W., 1987. Bee pollination and productivity growth: the case of alfalfa. American Journal of Agricultural Economics, 69, 56-63.

Olroyd, B. P., 2007. What's killing American honey bee ? PLoS Biology 5(6), e168.

Pimentel, D., Wilson, C., McCullum, C., Huang, R., Dwen, P., Flack, J., Tran, Q., Saltman, T., Cliff, B., 1997. Economic and environmental benefits of biodiversity. BioScience 47, 747-757.

Robinson, W. S., Nowogrodzki, R., Morse, R. A., 1989. The value of honey bees as pollinators of U.S. crops: Part II. American Bee Journal 129, 477-87.

Roubik, D. W., 2002. Tropical agriculture: The value of bees to the coffee harvest. Nature 417, 708 .

Roubik DW, Wolda H. 2001. Do competing honey bees matter? Dynamics and abundance of native bees before and after honey bee invasion. Population Ecology 43 :53-62.

Schubert, C., 2006. Can biofuels finally take center stage ? Nature Biotechnology 24, 777784.

Schröter, D., Polsky, C., Patt, A. G., 2005. Assessing vulnerabilities to the effects of global change: An eight step approach. Mitigation and Adaptation Strategies for Global Change 10, 573-596.

Settele, J., Hammen, V., Hulme, P., Karlson, U., Klotz, S., Kotarac, M., Kunin, W., Marion, G., O'Connor, M., Petanidou, T., Peterson, K., Potts, S., Pritchard, H., Pysek, P., Rounsevell, M., Spangenberg, J., Steffan-Dewenter, I., Sykes, M., Vighi, M., Zobel, M., 
Kühn, I., 2005. ALARM: Assessing large-scale environmental risks for biodiversity with tested methods. GAIA 14, 69-72.

Southwick, E. E., Southwick, L., 1992. Estimating the economic value of honey-bees (Hymenoptera, Apidae) as agricultural pollinators in the United-States. Journal of Economic Entomology 85, 621-633.

Steffan-Dewenter, 2003. Seed set of male-sterile an male-fertile oilseed rape (Brassica napus) in relation to pollinator density. Apidologie, 34, 227-235.

Stokstad, E., 2007. The case of the empty hives. Science 316, 970-972.

Sumner, D.A. and Boriss, H. 2006. Bee-conomics and the leap in pollination fees. ARE update, Univ. California, Giannini Foundation 9(3) Jan/Feb. 2006. http://www.agecon.ucdavis.edu/uploads/update_articles/v9n3_3.pdf

Tang K., 2005. Multi-agent and market based dynamic optimisation and its extensions to distributed supply chain procurement planning problems. $\mathrm{PhD}$ thesis, Pennsylvania State University, May 2005, 197 pp.

Turner, B.L., Kasperson, R.E., Matson, P., McCarthy, J.J., Corell, R.W., Christensen, L., Eckley, N., Kasperson, J.X., Luers, A., Martello, M.L., Mathiesen, S., Polsky, C., Pulsipher, A., Schiller, A. and Tyler, N., 2003. A framework for vulnerability analysis in sustainability science. Proceedings of the National Academy of Sciences USA 100, 80748079 .

United States Department of Agriculture. Statistical Database. Available at http://www.fas.usda.gov, Commodities and Products. Last accessed in October 2006.

Velthuis, H. H. W., van Doorn, A., 2006. A century of advances in bumblebee domestication and the economic and environmental aspects of its commercialization for pollination. Apidologie 37, 421-451.

White, G.F. 1974. Natural Hazards: Local, National and Global. Oxford University Press, New York. 304 pp.

Williams, I. H. 1994. The dependence of crop production within the European Union on pollination by honey bees. Agricultural Zoology Reviews 6, 229-257.

Winfree R., Williams N.M., Dushoff J., Kremen C., 2007. Native bees provide insurance against ongoing honey bee losses. Ecology Letters 10, 1105-1113.

Winfree R., Williams N.M., Gaines H., Ascher J.S., Kremen C., 2008. Wild bee pollinators provide the majority of crop visitation across land-use gradients in New Jersey and Pennsylvania, USA. Journal of Applied Ecology 45:793-802. 
1 World Health Organization, 1990. Diet, Nutrition and the Prevention of Chronic diseases. 2 Technical Report Series no. 797. Geneva: WHO.

3 Wu S.D., 2004. Supply chain intermediation: A bargaining theoretical framework. In D. 4 Simchi-Levi, S.D. Wu and Z.M. Shen (Eds.), Handbook of Quantitative Supply Chain 5 Analysis. Kluwer Academic Publishers, 67-115.

6 


\section{Tables and figures}

Table 1 - Heterogeneity of the production dependence ratios reported for some selected crops in regards to insect pollination (extrema are underlined).

Table 2 - Economic impact of insect pollination on the main categories of the world agricultural production used directly for human food and ranked by their rate of vulnerability to pollinator loss.

Table 3 - Geographical distribution of crop production value, economic impact of pollinators and vulnerability ratio among the 16 regions of the world defined following FAO (http://faostat.fao.org).

Table 4 - Economic vulnerability ratio (in bold) and 2005 production figures in $10^{6}$ metric tons (in italics) for the pollinator-dependent crop categories among the 16 regions of the world defined following FAO (http://faostat.fao.org). $\mathbf{X \%}$ highest value of the economic vulnerability ratio for the sub-region.

Table 5 - Effect of pollinator loss on the capacity to provide food at the world scale for the pollinator-dependent crop categories.

Table 6 - Regional effect of pollinator loss on the capacity to meet consumption before and after (in bold) total pollinator loss for the three crop categories for which the overall 2005 balance was negative following pollinator loss.

Table 7 - Consumer surplus loss at the world scale for 2005 in relation with price elasticity

Figure 1 - Estimates of the consumer surplus loss for different values of price elasticity 
Table 1 - Heterogeneity of the dependence ratios reported for the production of some selected crops in regards to insect pollination (extrema are underlined).

\begin{tabular}{|c|c|c|c|c|c|c|c|c|c|c|}
\hline \multirow[t]{2}{*}{ Crop species } & \multirow[t]{2}{*}{ Common name } & \multicolumn{3}{|c|}{ Borneck \& Bricout, 1984} & \multirow{2}{*}{$\begin{array}{c}\text { Robinson et } \\
\text { al., } 1989\end{array}$} & \multirow{2}{*}{$\begin{array}{c}\text { Southwick \& } \\
\text { Southwick, } \\
1992 \\
\end{array}$} & \multirow{2}{*}{$\begin{array}{c}\text { Morse \& } \\
\text { Calderone, } \\
2000\end{array}$} & \multicolumn{3}{|c|}{ Klein et al., 2007} \\
\hline & & $\operatorname{Min}$ & $\operatorname{Max}$ & Mean & & & & Min & $\operatorname{Max}$ & Mean \\
\hline \multicolumn{11}{|l|}{ FRUITS } \\
\hline Fragaria $\mathrm{x}$ ananassa & Strawberry & 0.100 & 0.200 & $\underline{0.150}$ & $\underline{0.4}$ & 0.30 & 0.2 & 0.1 & 0.4 & 0.25 \\
\hline Malus domestica & Apple & 0.100 & 0.200 & $\underline{0.150}$ & $\underline{1.0}$ & 0.80 & 1.0 & 0.4 & 0.9 & 0.65 \\
\hline Vitis vinifera & Grape & 0.001 & 0.010 & 0.006 & 0.1 & $\underline{0.15}$ & 0.1 & 0.0 & 0.0 & $\underline{0.00}$ \\
\hline \multicolumn{11}{|l|}{$\underline{\text { NUTS }}$} \\
\hline Amygdalus communis & Almond & 0.100 & 0.200 & $\underline{0.150}$ & $\underline{1.0}$ & 0.90 & 1.0 & 0.4 & 0.9 & 0.65 \\
\hline \multicolumn{11}{|l|}{ VEGETABLES } \\
\hline Cucumis melo & $\begin{array}{l}\text { Melon (incl. } \\
\text { cantaloupe) }\end{array}$ & 0.100 & 0.200 & $\underline{0.150}$ & 0.8 & 0.70 & 0.9 & 0.9 & 1.0 & $\underline{0.95}$ \\
\hline Mean & & & & 0.120 & 0.66 & 0.57 & 0.64 & & & 0.50 \\
\hline
\end{tabular}


Table 2 - Economic impact of insect pollination of the world agricultural production used directly for human food and listed by the main categories ranked by their rate of vulnerability to pollinator loss; the economic value of insect pollination was calculated following [1].

\begin{tabular}{ccccc}
\hline $\begin{array}{c}\text { Crop } \\
\text { category }\end{array}$ & $\begin{array}{c}\text { Average value } \\
\text { of a production } \\
\text { unit }\end{array}$ & $\begin{array}{c}\text { Total production } \\
\text { economic value } \\
(\mathrm{EV})\end{array}$ & $\begin{array}{c}\text { Insect } \\
\text { pollination } \\
\text { economic value } \\
\text { metric ton }\end{array}$ & $\begin{array}{c}\text { Rate of } \\
\text { vulnerability } \\
\text { (IPEV/EV) }\end{array}$ \\
\hline Stimulant crops & 1225 & $10^{9} €$ & $10^{9} €$ & $\%$ \\
Nuts & 1269 & 13 & 7.0 & 39.0 \\
Fruits & 452 & 219 & 4.2 & 31.0 \\
Edible oil crops & 385 & 240 & 50.6 & 23.1 \\
Vegetables & 468 & 418 & 39.0 & 16.3 \\
Pulse & 515 & 24 & 50.9 & 12.2 \\
Spices & 1003 & 7 & 1.0 & 4.3 \\
Cereals & 139 & 312 & 0.2 & 2.7 \\
Sugar crops & 177 & 268 & 0.0 & 0.0 \\
Roots \& tubers & 137 & 98 & 0.0 & 0.0 \\
\hline All categories pooled & & 1618 & 0.0 & 0.0 \\
together & & & 152.9 & 9.5 \\
\hline
\end{tabular}


Table 3 - Geographical distribution of crop production value, economic impact of pollinators and vulnerability ratio among the 16 sub-regions of the world defined following FAO (http://faostat.fao.org); the economic value of insect pollination was calculated following [1]; subregions with high vulnerability ratios $(\geq 10 \%)$ are in bold.

\begin{tabular}{|c|c|c|c|}
\hline $\begin{array}{l}\text { Geographical } \\
\text { region and sub- } \\
\text { region }\end{array}$ & $\begin{array}{l}\text { Total } \\
\text { production } \\
\text { economic } \\
\text { value } \\
(\mathrm{EV})\end{array}$ & $\begin{array}{l}\text { Insect pollination } \\
\text { economic value } \\
\text { (IPEV) }\end{array}$ & $\begin{array}{c}\text { Rate of } \\
\text { vulnerability for } \\
\text { the region } \\
\text { (IPEV/EV) }\end{array}$ \\
\hline & $10^{9} €$ & $10^{9} €$ & $\%$ \\
\hline \multicolumn{4}{|l|}{ AFRICA } \\
\hline Central Africa & 10.1 & 0.7 & 7 \\
\hline East Africa & 19.6 & 0.9 & 5 \\
\hline North Africa & 39.7 & 4.2 & 11 \\
\hline South Africa & 19.2 & 1.1 & 6 \\
\hline West Africa & 48.9 & 5.0 & 10 \\
\hline \multicolumn{4}{|l|}{ ASIA } \\
\hline Central Asia & 11.8 & 1.7 & 14 \\
\hline East Asia & 418.4 & 51.5 & 12 \\
\hline Middle East Asia & 63.5 & 9.3 & 15 \\
\hline Oceania & 18.8 & 1.3 & 7 \\
\hline South Asia & 219.4 & 14.0 & 6 \\
\hline South East Asia & 167.9 & 11.6 & 7 \\
\hline \multicolumn{4}{|l|}{ EUROPE } \\
\hline $\begin{array}{c}\text { European Union (25 } \\
\text { members) }\end{array}$ & 148.9 & 14.2 & 10 \\
\hline Non EU25 & 67.8 & 7.8 & 12 \\
\hline $\begin{array}{c}\text { NORTH AMERICA } \\
\text { Bermuda, Canada } \\
\text { \& USA }\end{array}$ & 125.7 & 14.4 & 11 \\
\hline \multicolumn{4}{|c|}{ SOUTH \& CENTRAL AMERICA } \\
\hline $\begin{array}{c}\text { Central America \& } \\
\text { Caribbean }\end{array}$ & 51.1 & 3.5 & 7 \\
\hline South America & 187.7 & 11.6 & 6 \\
\hline
\end{tabular}


Table 4 - Economic vulnerability ratio (in bold) and 2005 production figures in $10^{6}$ metric tons (in italics) for the pollinator-dependent crop categories among the 16 sub-regions of the world defined following FAO (http://faostat.fao.org). $\mathbf{X \%}$ highest value of the economic vulnerability ratio for the sub-region.

\begin{tabular}{|c|c|c|c|c|c|c|c|}
\hline $\begin{array}{l}\text { Geographical region and sub- } \\
\text { region }\end{array}$ & $\begin{array}{l}\text { Edible oil } \\
\text { crops }\end{array}$ & Fruits & Nuts & Pulse & Spices & $\begin{array}{l}\text { Stimulant } \\
\text { crops }\end{array}$ & Vegetables \\
\hline \multicolumn{8}{|l|}{ AFRICA } \\
\hline \multirow{2}{*}{ Central Africa } & $8 \%$ & $4 \%$ & $0 \%$ & $1 \%$ & $5 \%$ & $69 \%$ & $10 \%$ \\
\hline & 4.37 & 5.71 & 0.04 & 0.12 & 0.05 & 0.28 & 2.58 \\
\hline \multirow{2}{*}{ East Africa } & $18 \%$ & $4 \%$ & $22 \%$ & $10 \%$ & $3 \%$ & $17 \%$ & $4 \%$ \\
\hline & 2.08 & 6.39 & 0.18 & 1.70 & 0.18 & 1.05 & 6.85 \\
\hline \multirow{2}{*}{ North Africa } & $13 \%$ & $16 \%$ & $58 \%$ & $15 \%$ & $4 \%$ & - & $13 \%$ \\
\hline & 3.86 & 15.73 & 0.24 & 1.04 & 0.14 & 0 & 30.45 \\
\hline \multirow{2}{*}{ South Africa } & $17 \%$ & $15 \%$ & $45 \%$ & $0 \%$ & $25 \%$ & $16 \%$ & $8 \%$ \\
\hline & 2.74 & 7.95 & 0.08 & 0.41 & 0.06 & 0.16 & 4.11 \\
\hline \multirow{2}{*}{ West Africa } & $9 \%$ & $11 \%$ & $46 \%$ & $2 \%$ & $3 \%$ & $90 \%$ & $5 \%$ \\
\hline & 23.81 & 10.88 & 1.03 & 0.00 & 0.25 & 2.53 & 17.47 \\
\hline \multicolumn{8}{|l|}{ ASIA } \\
\hline \multirow{2}{*}{ Central Asia } & $25 \%$ & $41 \%$ & $35 \%$ & $4 \%$ & $4 \%$ & - & $14 \%$ \\
\hline & 4.00 & 2.16 & 0.03 & 0.06 & 0.00 & 0 & 8.59 \\
\hline \multirow{2}{*}{ East Asia } & $17 \%$ & $36 \%$ & $16 \%$ & $10 \%$ & $3 \%$ & $2 \%$ & $15 \%$ \\
\hline & 62.76 & 94.71 & 1.70 & 5.64 & 0.76 & 1.08 & 462.56 \\
\hline \multirow{2}{*}{ Middle East Asia } & $18 \%$ & $24 \%$ & $18 \%$ & $3 \%$ & $1 \%$ & $3 \%$ & $18 \%$ \\
\hline & 5.27 & 32.97 & 1.55 & 2.98 & 0.23 & 0.28 & 49.57 \\
\hline \multirow{2}{*}{ Oceania } & $24 \%$ & $28 \%$ & $33 \%$ & $6 \%$ & $1 \%$ & $94 \%$ & $8 \%$ \\
\hline & 3.69 & 5.08 & 0.05 & 2.14 & 0.01 & 0.01 & 2.86 \\
\hline \multirow{2}{*}{ South Asia } & $19 \%$ & $23 \%$ & $23 \%$ & $0 \%$ & $2 \%$ & $11 \%$ & $7 \%$ \\
\hline & 44.41 & 56.09 & 1.00 & 13.24 & 3.79 & 1.51 & 92.93 \\
\hline \multirow{2}{*}{ South East Asia } & $11 \%$ & $13 \%$ & $44 \%$ & $3 \%$ & $2 \%$ & $38 \%$ & $7 \%$ \\
\hline & 186.07 & 44.32 & 1.39 & 2.22 & 0.87 & 2.74 & 30.90 \\
\hline \multicolumn{8}{|l|}{ EUROPE } \\
\hline \multirow{2}{*}{ European Union (25 members) } & $8 \%$ & $30 \%$ & $48 \%$ & $5 \%$ & $1 \%$ & - & $7 \%$ \\
\hline & 31.94 & 60.05 & 0.82 & 5.49 & 0.13 & 0 & 65.35 \\
\hline \multirow{2}{*}{ Non EU25 } & $24 \%$ & $51 \%$ & $4 \%$ & $1 \%$ & $3 \%$ & $0 \%$ & $12 \%$ \\
\hline & 17.81 & 13.31 & 0.28 & 2.83 & 0.12 & 0.02 & 35.08 \\
\hline \multicolumn{8}{|l|}{ NORTH AMERICA } \\
\hline \multirow{2}{*}{ Bermuda, Canada \& USA } & $23 \%$ & $24 \%$ & $46 \%$ & $3 \%$ & $0 \%$ & - & $8 \%$ \\
\hline & 110.74 & 27.62 & 1.31 & 6.56 & 0.04 & 0 & 39.74 \\
\hline \multicolumn{8}{|c|}{ SOUTH \& CENTRAL AMERICA } \\
\hline \multirow{2}{*}{ Central America \& Caribbean } & $14 \%$ & $10 \%$ & $1 \%$ & $5 \%$ & $2 \%$ & $29 \%$ & $12 \%$ \\
\hline & 5.73 & 29.86 & 0.21 & 1.12 & 0.16 & 1.21 & 19.49 \\
\hline \multirow{2}{*}{ South America } & $22 \%$ & $9 \%$ & $25 \%$ & $9 \%$ & $3 \%$ & 30\% & $8 \%$ \\
\hline & 113.38 & 71.44 & 0.30 & 0.45 & 0.28 & 4.55 & 25.17 \\
\hline TOTAL & 622.66 & 484.27 & 10.21 & 46.00 & 7.07 & 15.42 & 893.70 \\
\hline
\end{tabular}


Table 5 - Effect of pollinator loss on the capacity to provide food at the world scale for the pollinator-dependent crop categories. The differences between 2005 production and consumption figures are expressed in relative terms as \% of the 2005 consumption figures following FAO (http://faostat.fao.org).

\begin{tabular}{lcc}
\hline \multirow{2}{*}{ Crop categories } & $\begin{array}{c}\text { Relative production } \\
\text { surplus before } \\
\text { pollinator loss }\end{array}$ & $\begin{array}{c}\text { Relative production } \\
\text { surplus after pollinator } \\
\text { loss }\end{array}$ \\
\cline { 2 - 3 } Stimulant crops & \multicolumn{2}{c}{ \% of consumption } \\
\cline { 2 - 3 } Fruits & 18 & $\mathbf{- 2 4}$ \\
Vegetables & 12 & $\mathbf{- 1 2}$ \\
Spices & 19 & $\mathbf{- 6}$ \\
Nuts & 11 & 8 \\
Edible oil crops & 29 & 16 \\
Pulses & 75 & 40 \\
\hline
\end{tabular}


Table 6 - Regional effect of pollinator loss on the capacity to meet consumption before and after (in bold) total pollinator loss for the three crop categories for which the 2005 overall balance was negative following pollinator loss. The differences between 2005 production and consumption figures are expressed in relative terms as \% of the 2005 consumption figures following FAO (http://faostat.fao.org).

Geographical region

(FAO classification)

Fruits Stimulant crops $\quad$ Vegetables

$\%$ of consumption

AFRICA

$\begin{array}{crrrrrr}\text { Central Africa } & 22 & \mathbf{1 6} & 633 & \mathbf{1 0 2} & -4 & \mathbf{- 1 6} \\ \text { East Africa } & -51 & \mathbf{- 5 4} & 369 & \mathbf{2 9 7} & 9 & \mathbf{5} \\ \text { North Africa } & 15 & \mathbf{- 4} & -100 & \mathbf{- 1 0 0} & 16 & \mathbf{- 1 3} \\ \text { South Africa } & 56 & \mathbf{2 9} & 10 & \mathbf{- 5} & 2 & \mathbf{- 1 1} \\ \text { West Africa } & -22 & \mathbf{- 2 8} & 2982 & \mathbf{1 6 9} & 21 & \mathbf{1 6}\end{array}$

ASIA

$\begin{array}{crrrrrr}\text { Central Asia } & 31 & \mathbf{- 2 2} & -100 & \mathbf{- 1 0 0} & 40 & \mathbf{5} \\ \text { East Asia } & 1 & \mathbf{- 2 6} & -30 & \mathbf{- 3 0} & 28 & \mathbf{- 4} \\ \text { Middle East Asia } & 31 & \mathbf{2} & -43 & \mathbf{- 4 3} & 31 & \mathbf{- 1 2} \\ \text { Oceania } & 60 & \mathbf{2 1} & -93 & \mathbf{- 1 0 0} & -4 & \mathbf{- 2 2} \\ \text { South Asia } & 20 & \mathbf{- 3} & 23 & \mathbf{4 5} & 9 & \mathbf{0} \\ \text { South East Asia } & 30 & \mathbf{2 0} & 289 & \mathbf{1 4 0} & 15 & \mathbf{6}\end{array}$

EUROPE

European Union $(25$ members)

$-20$

$\begin{array}{lllll}\mathbf{- 4 0} & -100 & \mathbf{- 1 0 0} & -3 & \mathbf{- 1 6}\end{array}$

Non EU25

$-30$

$-61$

$-98$

$\mathbf{- 9 8}-2$

$-23$

NORTH AMERICA

Bermuda. Canada \& USA $\quad-30$

$-30$

$-46$

$-100$

$-100$

$-16$

SOUTH \& CENTRAL

AMERICA

Central America \&

Caribbean

54

35

183

$99 \quad 63$

27

South America

83

65

176

103

17

$-4$ 
Table 7 - Consumer surplus loss at the world scale for 2005 in relation with price elasticity

\begin{tabular}{|c|c|}
\hline $\begin{array}{l}\text { Price elasticity } \\
\text { parameter }\end{array}$ & $\begin{array}{c}\text { Consumer surplus } \\
\operatorname{loss}\left(10^{9} €\right)\end{array}$ \\
\hline$-0,50$ & 422 \\
\hline$-0,60$ & 378 \\
\hline$-0,70$ & 341 \\
\hline$-0,80$ & 310 \\
\hline$-0,90$ & 285 \\
\hline$-1,00$ & 263 \\
\hline$-1,10$ & 244 \\
\hline$-1,20$ & 228 \\
\hline$-1,30$ & 214 \\
\hline$-1,40$ & 202 \\
\hline$-1,50$ & 191 \\
\hline$-1,60$ & 182 \\
\hline$-1,70$ & 173 \\
\hline$-1,80$ & 166 \\
\hline$-1,90$ & 159 \\
\hline$-2,00$ & 153 \\
\hline
\end{tabular}


Figure 1 - Estimates of the consumer surplus loss for different values of price elasticity

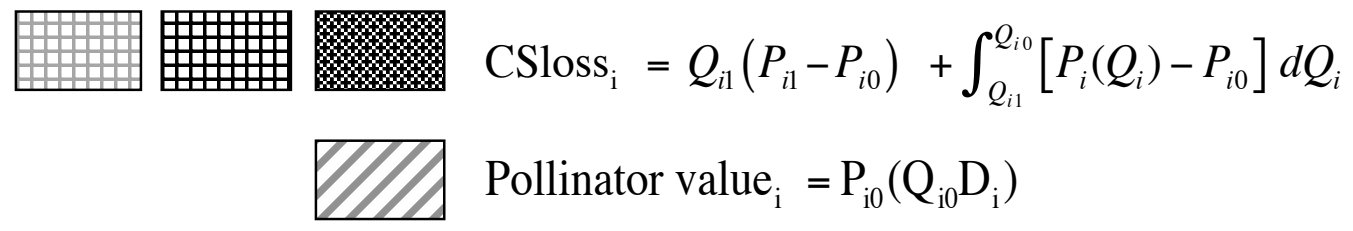

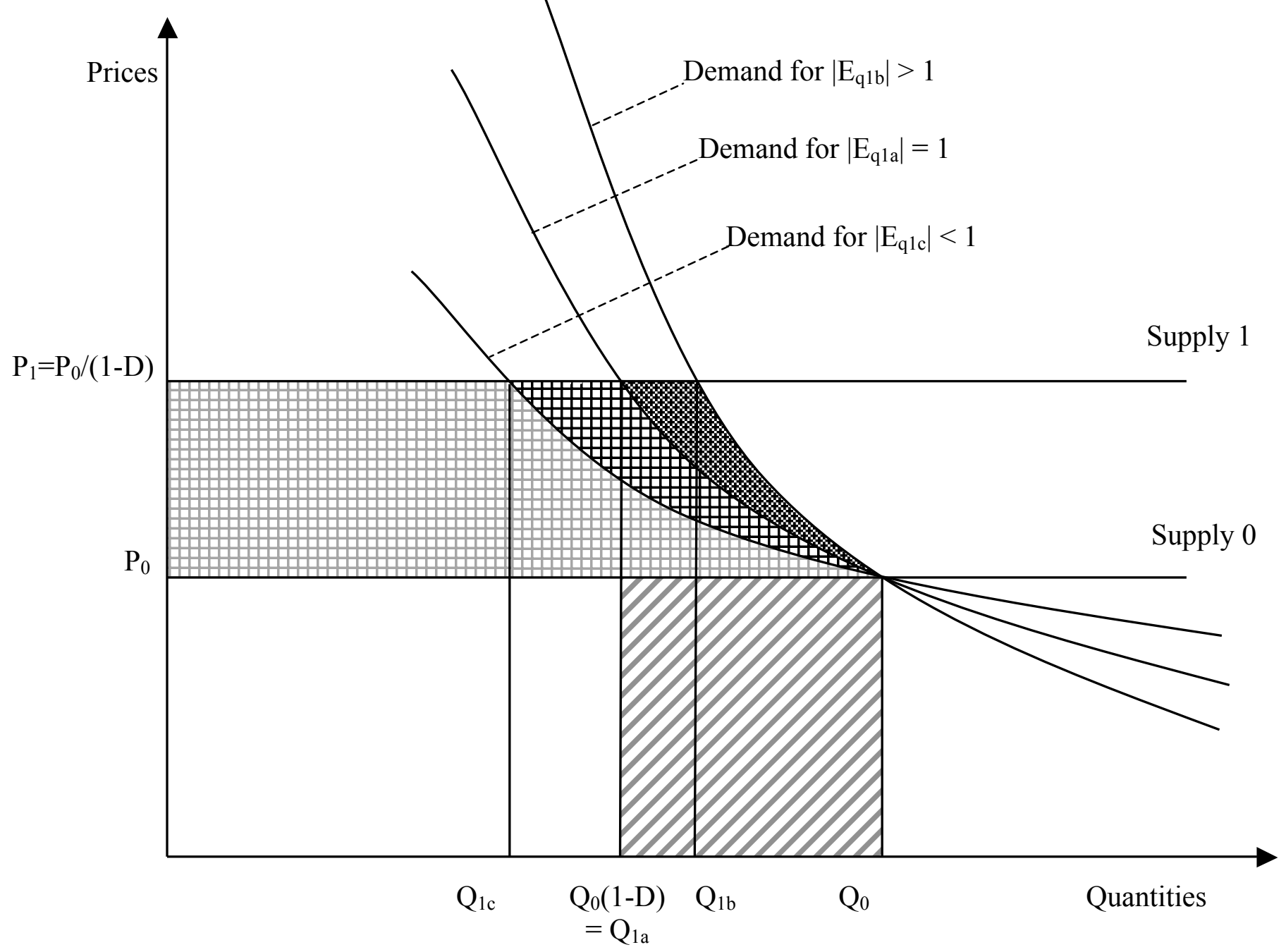

